\section{Kidney \\ Blood Pressure Research}

Original Paper

\title{
Matrix Gla Protein is Involved in Crystal Formation in Kidney of Hyperoxaluric Rats
}

\author{
Xiuli Lu Bing Gao ${ }^{\mathrm{b}, c}$ Takahiro Yasui b,d Yang Lia Ting Liu ${ }^{\mathrm{a}}$ Xu Mao ${ }^{\mathrm{b}}$ Masahito \\ Hirose $^{b, d} \quad$ Yuhong Wu ${ }^{b}$ Daojun Yu ${ }^{b}$ Qiwen Zhu ${ }^{b}$ Kenjiro Kohrib, ${ }^{b}$ Chunling \\ Xiao ${ }^{b, c}$
}

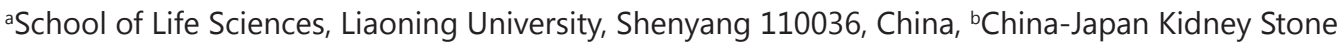
Research Center, Shenyang Medical College, 146 Huanghe North Street, Shenyang 110034, China, cKey Laboratory of Environment and Population Health of Liaoning Education Ministry, Shenyang Medical College, Shenyang 110034, China, dDepartment of Nephro-urology, Nagoya City University Graduate School of Medical Sciences, 1 Kawasumi Mizuho-cho. Nagoya 467-8601, Japan

\section{Key Words}

Matrix Gla protein $•$ Kidney stone $\cdot$ Hyperoxaluria

\begin{abstract}
Background: Matrix Gla protein (MGP) is a molecular determinant regulating vascular calcification of the extracellular matrix. However, it is still unclear how MGP may be invovled in crystal formation in the kidney of hyperoxaluric rats. Methods: Male Sprague-Dawley rats were divided into the hyperoxaluric group and control group. Hyperoxaluric rats were administrated by $0.75 \%$ ethylene glycol (EG) for up to 8 weeks. Renal MGP expression was detected by the standard avidin-biotin complex $(A B C)$ method. Renal crystal deposition was observed by a polarizing microscope. Total RNA and protein from the rat kidney tissue were extracted. The levels of MGP mRNA and protein expression were analyzed by the real-time polymerase chain reaction (RT-PCR) and Western blot. Results: Hyperoxaluria was induced successfully in rats. The MGP was polarly distributed, on the apical membrane of renal tubular epithelial cells, and was found in the ascending thick limbs of Henle's loop (cTAL) and the distal convoluted tubule (DCT) in hyperoxaluric rats, its expression however, was present in the medullary collecting duct (MCD) in stone-forming rats. Crystals with multilaminated structure formed in the injurious renal tubules with lack of MGP expression.MGP mRNA expression was significantly upregulated by the crystals' stimulations. Conclusion: Our results suggested that the MGP was involved in crystals formation by the continuous expression, distributing it polarly in the renal tubular cells and binding directly to the crystals.
\end{abstract}

Copyright (C) 2013 S. Karger AG, Basel 


\section{Kidney \\ Blood Pressure Research}

Kidney Blood Press Res 2013;37:15-23

\begin{tabular}{l|l}
\hline DOI: 10.1159/000343396 & (c) 2013 S. Karger AG, Basel
\end{tabular}

Published online: February 26, 2013

www.karger.com/kbr

Lu/Gao/Yasui/Li/Liu/Mao/Hirose/Wu/Yu/Zhu/Kohri/Xiao: Matrix Gla Protein and Kidney Stone Formation

\section{Introduction}

Kidney stone is a common ectopic calcification similar to vascular calcification. About 2-5\% of the population in Asia and 8-15\% in Europe and North America develop renal stones in their lifetime [1]. Kidney stone formation is a complex event and results from imbalance of promoting and inhibiting factors. Hyperoxaluria is a major risk factor for forming calcium oxalate stone, the most common stone type. At the same time, some macromolecules have been identified in both the urine and kidney stone matrix and modulate the interaction between renal epithelial cells and crystals or oxalate over the years [2]. These proteins exist extensively both in healthy and stone-forming individuals and modulate the crystal nucleation, growth, aggregation and adhesion to renal epithelial cells, and greatly affect the risk of forming stones $[3,4]$. Stones may arise from abnormalities of compromises in these interactions.

MGP, a vitamin K-dependent extracellular matrix protein, was originally isolated from the bone and also expressed in several soft tissues including the lung, heart, vascular smooth muscle cells of the blood vessel wall and kidney [5]. MGP is an 84-amino-acid protein that contains five $\gamma$-carboxyglutamic acid (Gla) residues which has a high affinity for calcium and phosphate ions, and hydroxyapatite crystals [6]. Luo et al. found that homozygous MGPdeficient mice died within 8 weeks as a result of arterial calcification that led to blood vessel rupture [7]. Vascular calcification in MGP-deficient mice was reversed by over expressing MGP in vascular smooth muscle cells [8]. These results imply that MGP is a molecular determinant regulating vascular calcification of the extracellular matrix. The pathological mechanism of kidney stone formation was at least partly analogous to vascular calcification, such as forming calcific plaques, increasing expression of calcification inhibitors and regulating actively calcification process. We previously reported that MGP mRNA expression was upregulated in renal tubular epithelial cells following exposure to calcium oxalate monohydrate (COM) and oxalate [9], MGP genetic single nucleotide polymorphism was associated with the individual susceptibility of nephrolithiasis [10]. However, it was still unclear how MGP may be involved in the crystal formation in the kidney.

In the present study, we performed further immunohistological staining, Western blot, and quantitative real-time PCR to analyse MGP expression, location, and interaction with crystal in the kidney of hyperoxaluric rat. We found that MGP expression was present in CTAL and DCT in normal and hyperoxaluric rats, but in the MCD in stone-forming rats. A polar distribution of MGP on the apical membrane of renal tubular epithelial cells suggested that it might have direct interaction with crystals and oxalate on exposure.

\section{Materials and Methods}

\section{Animal Models}

Male Sprague-Dawley rats weighing 150 to $180 \mathrm{~g}$ were divided into two groups, hyperoxaluric group $(n=25)$ and control group $(n=5)$. Hyperoxaluria were induced by $0.75 \%$ EG in drinking water for up to 8 weeks and the control group was given plain water. All rats were housed in normal cages in an environment with a 12-hour light dark cycle, controlled temperature $\left(20 \pm 2{ }^{\circ} \mathrm{C}\right)$ and humidity $(50 \pm 10 \%)$. Rats were killed at 0 and 3 days, and 1, 2, 4 and 8-week intervals, respectively. The kidneys were removed after sufficient reperfusion. The left kidneys were stored in liquid nitrogen for molecular biological studies, and the right kidneys were fixed in $4 \%$ paraformaldehyde for histochemical studies. Twenty-four hour urine samples from rats were assayed for oxalate and calcium. The experiment was reviewed and approved by the Shenyang Medical College Animal Committee. 


\section{Kidney \\ Blood Pressure Research}

Kidney Blood Press Res 2013;37:15-23

\begin{tabular}{l|l}
\hline DOI: $10.1159 / 000343396$ & (c) 2013 S. Karger AG, Basel
\end{tabular}

Published onlıne: February 26, 2013

www.karger.com/kbr

Lu/Gao/Yasui/Li/Liu/Mao/Hirose/Wu/Yu/Zhu/Kohri/Xiao: Matrix Gla Protein and Kidney Stone Formation

Immunohistochemistry

$5 \mu \mathrm{m}$ thick paraffin sections were prepared from $4 \%$ paraformaldehyde fixed paraffin-embedded rat kidney. Each section was incubated overnight at $4^{\circ} \mathrm{C}$ with polyclonal rabbit anti-mouse matrix Gla protein antibody (TransGenic) diluted at 1:200. Then, the standard ABC (avidin-biotin complex) method was used. Briefly, the slides were incubated for 20 minutes with the secondary antibody (biotin conjugated rabbit anti-mouse IgG; Vector, USA) at a concentration of 1:200. The avidin-biotin Vectastain ABC system (Vector, Burlingame, CA) was then applied for 20 minutes. Sections were rinsed, treated with 3,3'-diaminobenzidine, counterstained with hematoxylin, and examined using a light microscope and polarizing microscope.

\section{RNA Preparation}

Total RNA from the kidney tissue was extracted with an ISOGEN kit (Nippon Gene, Toyama, Japan), and treated with DNase I for $30 \mathrm{~min}$ at $37^{\circ} \mathrm{C}$ followed by phenol chloroform extraction to avoid genomic DNA contamination. RNA concentrations were quantified spectrophotometrically at $260 \mathrm{~nm}$. RNA integrity was verified by ethidium bromide staining of $28 \mathrm{~S}$ and $18 \mathrm{~S}$ rRNA after agarose gel electrophoresis. Samples (500ng) were reverse transcribed to synthesize first-strand cDNA using oligo(dT)12-18 primer and Superscript II reverse transcriptase (Invitrogen, Carlsbad, CA) in $20 \mu \mathrm{l}$ reactions according to the manufacturer's instructions.

\section{Quantitative Real-time PCR}

To validate the expression of MGP genes in the tissue, the real-time polymerase chain reaction (RT-PCR) was performed in 96-well plates on the ABI Prism 7300 Sequence Detection System (Applied Biosystems, Foster City, CA). The sequence of primers and the TaqMan probe used for the analysis of MGP was obtained with the Assays-on-Demand Applied Biosystems database (order\# 185253029). The endogenous control, glyceraldehyde-3-phosphate dehydrogenase gene (GAPDH) (Applied Biosystems), was used to normalize variations in the cDNA quantities from different samples. The standard curve was constructed, in each of the experimental repetitions, by 5 -fold serial dilutions of cDNA, 1:5, 1:10, 1:50, 1:100, 1:500 and 1:1,000. The quantity of the target and endogenous control was determined from a standard curve for each experimental sample. Two-step reverse transcription-PCR was performed. The final reaction volume was $50 \mu \mathrm{l}$. Each sample was analyzed in triplicate. All of the experiments were repeated twice. Non-template control (RNasefree water) was included on every plate. Thermal cycler conditions were $2 \mathrm{~min}$ hold at $50^{\circ} \mathrm{C}, 10 \mathrm{~min}$ hold at $95^{\circ} \mathrm{C}$, followed by 40 cycles of $15 \mathrm{~s}$ at $95^{\circ} \mathrm{C}$ (denaturation) and $1 \mathrm{~min}$ at $60^{\circ} \mathrm{C}$ (annealing/extension). The comparative standard curve and the threshold cycle method were used to calculate the amplification factor.

\section{Western Blot}

The protein was isolated from the kidneys by the homogenization in the celLyticTM MT Mammalian Tissue Lysis/Extraction reagent (Sigma) with protease inhibitors. For Western blot analysis, $50 \mu \mathrm{g}$ of protein were resolved on 5-20\% SDS-PAGE gel and then transferred onto immobilon-p transfer membrane (Millipore, Billerica, USA). Membranes were blocked using 5\% nonfat milk/TBS for 60 minutes and incubated overnight at $4{ }^{\circ} \mathrm{C}$ with polyclonal rabbit anti-mouse matrix Gla protein antibody (TransGenic) diluted at 1:500. After washing, the membranes were incubated for 1 hour with a peroxidase-labeled secondary antibody (1:1,000; Amersham Pharmacia Biotech) at room temperature. After rewashing, the bands were visualized using peroxidase-linked ECL Western blotting detection reagents and the associated analysis system (Amersham Pharmacia Biotech). $\beta$-Actin antibody (Sigma Diagnostics, St. Louis, MO) was used to confirm equal protein loading among samples. All experiments were repeated in triplicate.

Statistical analysis

Statistical analysis was performed with an One-Way analysis of variance (ANOVA) using SPSS statistical software (version 10.0; SPSS Inc., Chicago, Illinois, USA). A $p$ value of $\leq 0.05$ was considered to be significant.

\section{Results}

Hyperoxaluric rat

Hyperoxaluria was induced successfully in rats. The urinary excretion of oxalate was 


\section{Kidney \\ Blood Pressure \\ Research}

Kidney Blood Press Res 2013;37:15-23

\begin{tabular}{l|l}
\hline DOI: $10.1159 / 000343396$ & (c) 2013 S. Karger AG, Basel
\end{tabular}

Published onIIne: February 26, 2013

www.karger.com/kbr

Lu/Gao/Yasui/Li/Liu/Mao/Hirose/Wu/Yu/Zhu/Kohri/Xiao: Matrix Gla Protein and Kidney Stone Formation

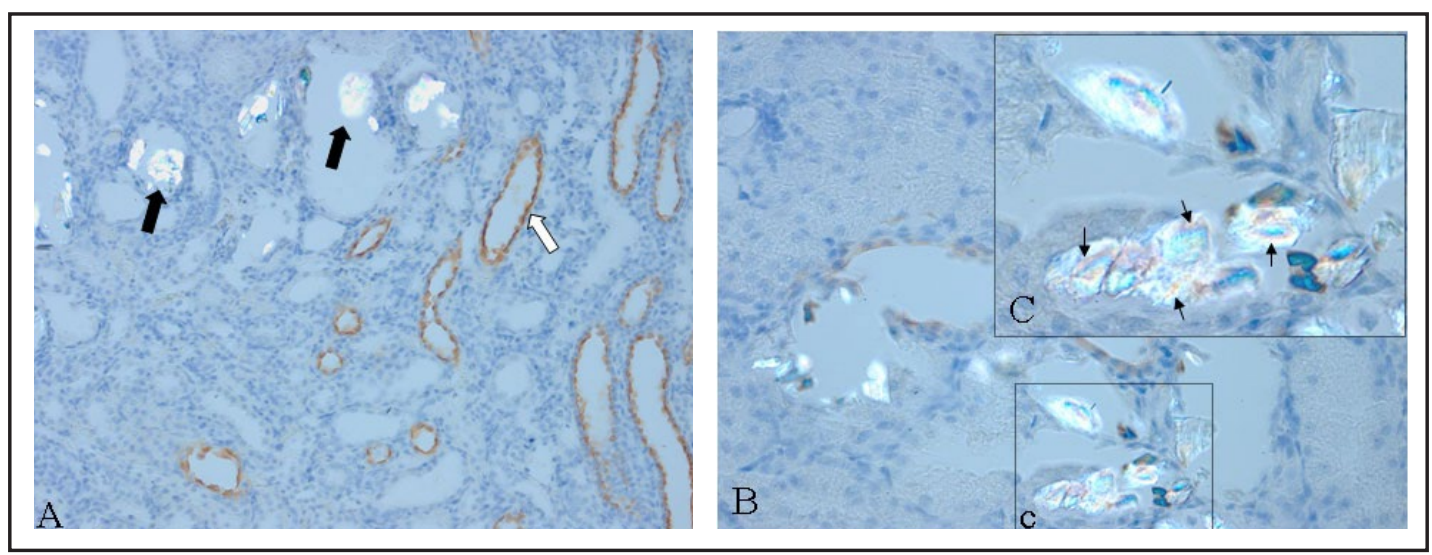

Fig. 1. The renal crystal formation in the hyperoxaluria rat under a polarizing microscope. (A) crystals (black arrow) deposited in the injurious renal tubules without intact MGP expression, and there was no crystal formation in the renal tubules with intact MGP expression (white arrow). (B and C) crystals were multilaminated structure in which inorganic and organic layers (black arrow) alternate. The crystal-matrix boundary was clear. (Magnification: 200x A and B; 400x C).

increased 3.4 7.5-fold compared with controls (127.1 $\pm 32.2 \mathrm{mg} / \mathrm{l})$ from the 3rd day (775.9 $\pm 97.9 \mathrm{mg} / \mathrm{l})$ to the 8 th week $(434.2 \pm 108.9 \mathrm{mg} / \mathrm{l})$, and the peak value was observed after 1 week $(954.2 \pm 277.9 \mathrm{mg} / \mathrm{l})$. The urinary excretion of calcium did not change significantly from 0 day $(6.8 \pm 2.1 \mathrm{mmol})$ to eight weeks $(6.4 \pm 0.63 \mathrm{mmol})$. Our rat model eliminated the effect of hypercalciuria.

\section{Crystal deposition}

Crystals were detected in the renal tubules in 3 out of 5 rats administered $0.75 \%$ EG for eight weeks using polarizing microscopy. Crystals deposited in the injured renal tubules without MGP expression, and there was no crystal formation in the renal tubules with intact MGP expression (Figure 1A). Crystals were observed to have multilaminated structure with inorganic and organic layers alternation. The crystal-matrix boundary was clear. A central layer appeared as damaged cell material. A brown middle layer, which looks like matrix protein material, surrounded the central layer, demonstrating that the MGP was present in the middle layer. The outer layer was light crystalline material (Figure $1 \mathrm{~B} \& \mathrm{C}$ ). This finding strongly suggests that MGP may affect crystal formation by binding to the crystals directly.

\section{Immunohistological localization of MGP in rat kidney}

Figures 2 \& 3 showed the results of the immunohistochemical location of MGP in the kidneys of the control, hyperoxaluric and stone-forming rat. In the control and hyperoxaluric rats, MGP widely located in CTAL and DCT in the region of medulla and in the papilla, and scatteredly in the cortex (Figure 2A, 2B, 2C, 2D and 3A), and the location and intensity of staining was not obviously different. However, in the stone-forming rat, MGP expression was present in the medullary collecting duct (MCD) in the medulla and papilla (Figure 2E, 2F and 3B).

Expression of MGP $m R N A$ and protein in rat kidney

As shown in Figure 4A, increased in MGP mRNA expression was insignificant in hyperoxaluric rats compared with the control rats 1.5 -fold at $3^{\text {rd }}$ day and 1.6-fold at the $4^{\text {th }}$ week). However, the MGP mRNA expression increased remarkably by 14.7 -fold in stoneforming rats during the $8^{\text {th }}$ week compared with the control rats $(\mathrm{P}<0.001)$. Figure $4 \mathrm{~B}$ shows MGP protein expression increased in rats from the $3^{\text {rd }}$ day to the $4^{\text {th }}$ week, and reduced to the normal level in the $8^{\text {th }}$ week. MGP mRNA and protein expression were consistent in control 


\section{Kidney Blood Pressure Research}

Fig. 2. The matrix Gla protein (MGP) expression location in the kidney of normal, hyperoxaluric (Treatment for 4 weeks) and the stone-forming (Treatment for 8 weeks) rat under light microscopy. MGP are expressed in cTAL and DCT in the region of medulla and in papilla, scatteredly in the cortex. The location and intensity of staining was not obviously altered in rats administered with $1 \%$ EG from 0 to 4 weeks (A, B, $C, D)$. In the stone-forming rat, MGP expressed in the medullary collecting duct (MCD) of the medulla and papilla. The number of positive staining reduced $(\mathrm{E}, \quad \mathrm{F})$. (Magnification: $\times 200$ ).

Lu/Gao/Yasui/Li/Liu/Mao/Hirose/Wu/Yu/Zhu/Kohri/Xiao: Matrix Gla Protein and Kidney Stone Formation

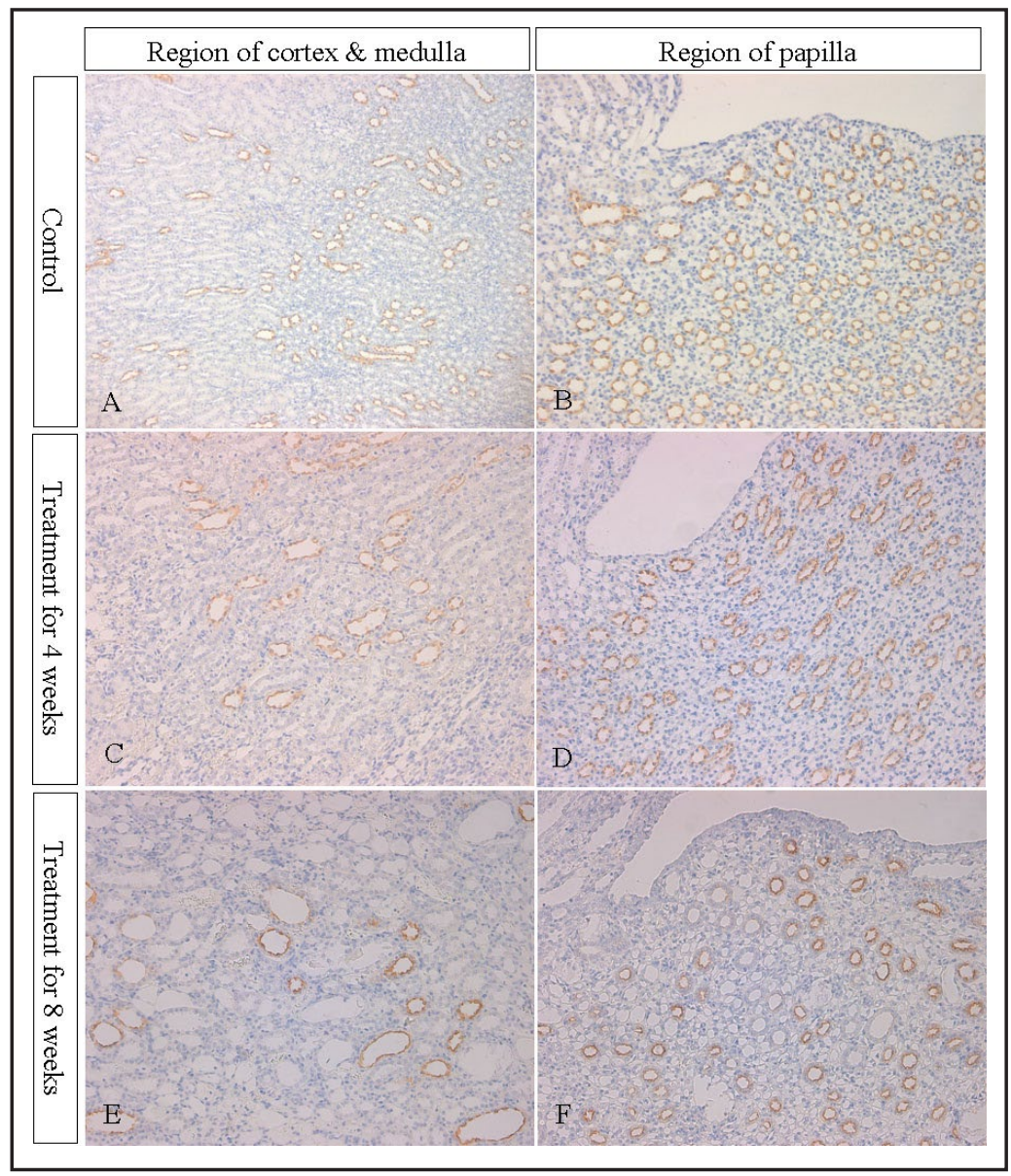

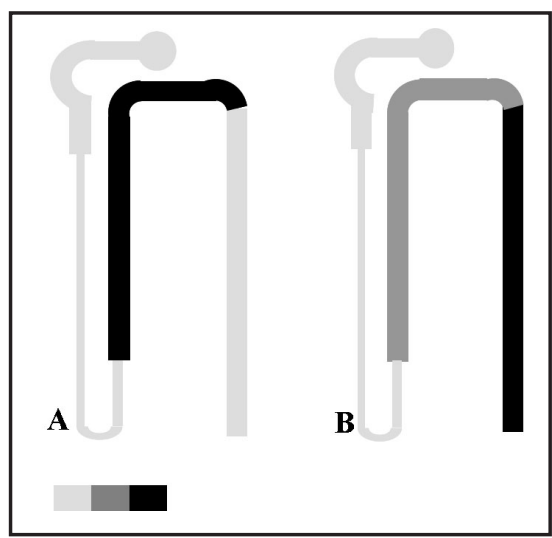

Fig. 3. A schematic diagram of MGP expression in single nephron before (A) and after (B) stone formation. The black represents the strong expression and the gray represents the weak MGP expression.

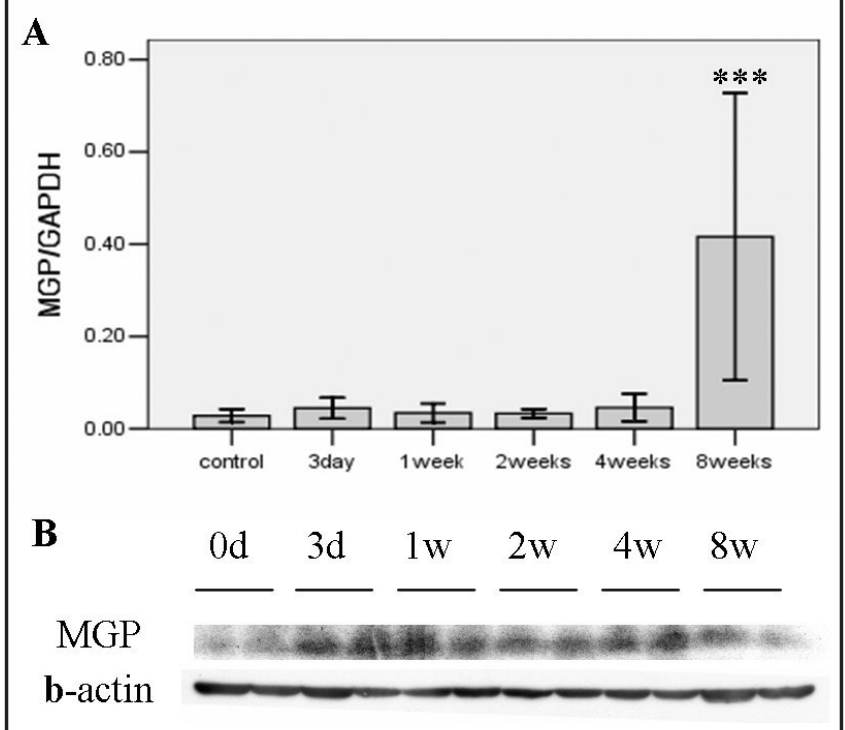

Fig. 4. MGP expression in the kidney of treatment rats. (A) MGP mRNA expression by quantitative real-time PCR and (B) MGP protein expression by Western blotting in the treatment rat from 0 day to 8 weeks. ${ }^{* * *} \mathrm{P}<0.001$ vs. control. 


\section{Kidney Blood Pressure Research}

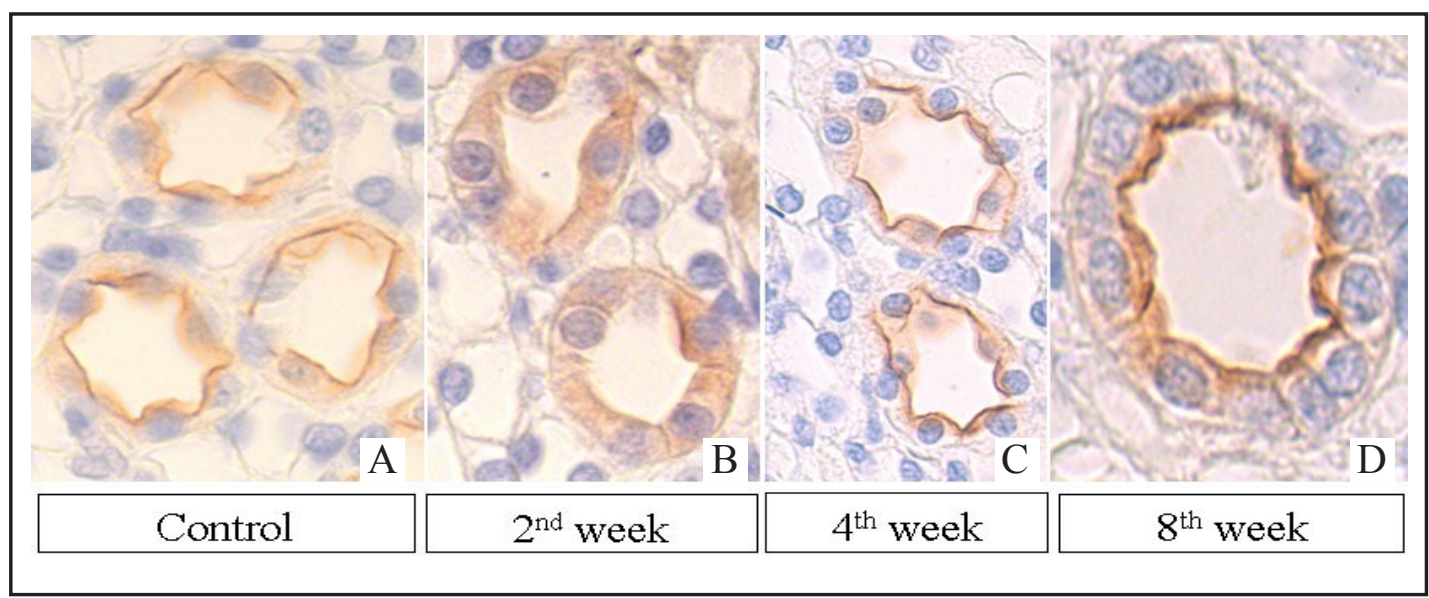

Fig. 5. Polar distribution of MGP in the apical membrane of renal epithelium cells. MGP was obviously polarly distributed, like a barrier, in the apical membrane of renal tubular epithelial cells including cTAL and MCD in control, hyperoxaluria and stone-forming rats (A, C, D). MGP distributed in the cytoplasm of renal tubular epithelial cells in the rats administrated with 0.75\% EG for 2 weeks (B). (Magnification: $\times 400$ ).

and hyperoxaluric rats, and showed a markedly inverse correlation in stone-forming rats. These results demonstrated that crystals significantly induced MGP mRNA expression.

Polar distribution of MGP in the renal epithelium cells

MGP showed a distinct polar distribution in the apical membrane of renal tubular epithelial cells including CTAL and MCD in control, hyperoxaluric and stone-forming rats (Figure 5A, 5C, 5D). MGP was also observed with a diffused distribution throughout the cytoplasm of renal tubular epithelial cells in the $2^{\text {nd }}$ week-rat (Figure 5B). These results indicated that MGP is transported from cytoplasm to the apical membrane of cells under the hyperoxaluria exposure and exert its function there.

\section{Disscusion}

Previous studies regarding kidney stone indicated that the complex interactions between oxalate ion/crystals and renal tubular cells are an actively regulated process. These observations have led to a search for the molecular determinants of kidney stone. MGP is a natural inhibitor of vascular calcification. However, its role in forming renal stone is still unclear. In this study, we investigated whether MGP may be invovled in crystal formation in the kidney of hyperoxaluric rats. Our research design excluded the possibility of hypercalciuric disorder. This strategy allowed us to discover previously unreported results. These findings suggest that the MGP may be involved in crystals formation by continual expression, distributing polarly in renal tubular cells and binding directly to crystals.

The kidney stone formation is a complex process. Different metabolized disorders may lead to different pathogenesis of calcium stone formation. A study by Evan et al. showed that hypercalciuria leads to the initial formation of calcium plaques in the basement membrane of the thin limbs of the loop of Henle, extending to the vasa recta and interstitial tissue and finally to the papillae, whereas hyperoxaluria caused renal calcification initially in papillary collecting ducts, and epithelial cell death and surrounding interstitial inflammation [11]. This finding suggested that the pathogenesis of calcium oxalate stone formation between hyperoxaluric and hypercalciuric disorder is different. To study calcium oxalate kidney stone, an animal model should be induced independently on hyperoxaluric or hypercalciuric disorder. In a previous study, calcium oxalate stone-forming rat was administered daily 


\section{Kidney Blood Pressure Research}

with vitamin D3 and 5\% EG [12]. Vitamin D is an important regulator of intestinal calcium absorption. An administration of small-dose vitamin D3 increased significantly the calcium absorption, and may induce hypercalciuria [13]. Therefore, In order to eliminate the effect of hypercalciuria, the rats were only induced hyperoxaluria by administrating $0.75 \%$ EG in the present study.

The first major finding is that MGP was expressed in CTAL and DCT of the normal and hyperoxaluric rats, and in the MCD of stone-forming rats. It is a new finding that is not completely consistent with the previous report that MGP expressed in proximal cortical and medullary tubules by Yasui et al. [12]. Our result showed that MGP expressed mainly in medulla, papilla and scatteredly in the cortex region. The reason for the difference may lie in the different administrating methods described above. However, our results are similar to osteopontin (OPN) expression, an essential inhibitor of stone formation. Kohri et al. previously reported that OPN mRNA expressed in DCT in control rats, and upregulated expression in DCT and MCD in stone-forming rats [2]. Tamm-Horsfall protein (THP), other one critical renal defense protein protecting against calcium oxalate crystal formation, was also reported to be secreted by epithelial cells in the cTAL and DCT in medulla, but not in papilla $[3,14]$. The concentration of oxalate is higher in the MCD than in other tubules [15]. Translocated expression of MGP and OPN in stone-forming rats indicated that these proteins may contribute to renal epithelial cells in MCD to have a greater capacity to withstand a severe hyperoxaluria and crystal stimulation. Similarly the location expressed a pattern among MGP, OPN and THP and also suggested that they may exert a collaborative role in stone formation.

The second major finding is that MGP was continuously expressed and distributed polarly on the apical membrane of renal tubular epithelial cells under normal, hyperoxaluric and crystal formation conditions, where it may be involved in interacting with crystal and oxalate ion. This finding suggested that MGP may undergo high-efficient intracellular transport which may be important for exerting its function. Mature MGP needs to undergo two types of posttranslational modification including $\gamma$-glutamate carboxylation in endoplasmic reticulum and serine phosphorylation in Golgi apparatus [16]. $\gamma$-glutamate carboxylation in Gla-residues provides MGP activity, and serine phosphorylation of MGP plays a role in regulating the secretion of proteins into the extracellular environment [17]. Chen et al. reported that renal vitamin k-dependent gamma-glutamyl carboxylase activity decreased in calcium oxalate calculi patients [18]. This finding suggested the abnormal activity and transport of MGP may influence the risk of kidney stones. However, it is still unclear how oxalate or crystal exposure affects posttranslational modification of MGP.

The third major finding is that no crystal forms in the renal tubules with MGP expression, and crystals only deposit in the damaged renal tubules with lack of MGP expression. MGP is previously reported to be involved in cell growth, differentiation and regulation of apoptosis, and increase cell density in normal kidney cells [19]. These findings suggested MGP may play a cytoprotective role in maintaining cells survival and inhibiting crystal retention under oxalate and crystal exposure. Once the balance is broken, MGP may affect renal crystal formation by binding to the crystals. We found that crystals formed multilaminated structure with alternation of inorganic and organic layers. The organic layers were stained same as MGP in renal tubular epithelia cells. The crystal nidus with blue stain may be apoptotic bodies or cell debris, and MGP surrounds the inner nidus and binds to the outer layer of the crystal. MGP has previously been detected in apoptotic bodies produced by vascular smooth muscle cells (VSMC ) [20]. And MGP mRNA expression was increased when apoptosis was induced in rat [21]. Apoptotic bodies derived from VSMC can act as a nidus for calcium crystal formation and these structures have been detected in both atherosclerotic lesions and Monckberg's sclerosis [22]. Price et al. explained the strong calcification inhibitory activity of MGP by its binding tightly to the crystal nuclei thus preventing further growth in vascular 


\section{Kidney \\ Blood Pressure Research}

Kidney Blood Press Res 2013;37:15-23

\begin{tabular}{l|l}
\hline DOI: $10.1159 / 000343396$ & (c) 2013 S. Karger AG, Basel
\end{tabular}

Published onlıne: February 26, 2013

www.karger.com/kbr

Lu/Gao/Yasui/Li/Liu/Mao/Hirose/Wu/Yu/Zhu/Kohri/Xiao: Matrix Gla Protein and Kidney Stone Formation

calcification [23]. However, it is unclear whether MGP plays an inhibiting or promoting role in crystal formation by binding to the crystals in renal tubules. These definite conclusions will be validated by studies in the future.

Finally, a main limitation of the present study was that we did not measure the concentration of MGP in the urine of the rat. Our result showed MGP mRNA and protein expressions were consistent in control and hyperoxaluric rats, and showed an inverse correlation in stone-forming rats. A consideration was that MGP, as a small secretory protein, may be secreted largely into the tubular lumen or coat crystals under severe conditions. As an insoluble matrix protein, the residues of gamma-carboxyglutamic acid have been found in urine and stone matrix [24].

\section{Conclusion}

MGP was continuously expressed and distributed polarly on the apical membrane of renal tubular epithelial cells, and involved in stone formation by binding directly to the crystals. Further study on the molecular mechanism of MGP function may provide opportunities for the development of novel therapeutic drug treatment for renal stone disease.

\section{Conflict of Interests}

The authors of this manuscript declare that they have no conflicts of interest.

\section{Acknowledgements}

This study was supported by grants from National Natural Science Foundation of China (no. 31171111), Human resources and Social Security Bureau and the Scientific Research Foundation for Liaoning Provincial Education Board (no. LTQ2011110). Thank you to Ms. Saba Rasheed Mir, Ms. Deborah Daniels and Dr. Newton Emmanuel for assisting this manuscript.

\section{References}

1 Pak CY: Kidney stones. Lancet 1998;351:1797-1801.

- Kohri K, Nomura S, Kitamura Y, Nagata T, Yoshioka K, Iguchi M, Yamate T, Umekawa T, Suzuki Y, Sinohara $\mathrm{H}$ : Structure and expression of the mRNA encoding urinary stone protein (osteopontin). J Biol Chem 1993;268:15180-15184.

3 Mo L, Huang HY, Zhu XH, Shapiro E, Hasty DL, Wu XR: Tamm-Horsfall protein is a critical renal defense factor protecting against calcium oxalate crystal formation. Kidney Int 2004;66:1159-1166.

-4 Qiu SR, Wierzbicki A, Orme CA, Cody AM, Hoyer JR, Nancollas GH, Zepeda S, De Yoreo JJ: Molecular modulation of calcium oxalate crystallization by osteopontin and citrate. Proc Natl Acad Sci USA 2004;101:1811-1815.

-5 Fraser JD, Price PA: Lung, heart, and kidney express high levels of mRNA for the vitamin K-dependent matrix Gla protein. Implications for the possible functions of matrix Gla protein and for the tissue distribution of the gamma-carboxylase. J Biol Chem 1988;263:11033-11036.

6 Proudfoot D, Shanahan CM: Molecular mechanisms mediating vascular calcification: role of matrix Gla protein. Nephrology (Carlton) 2006;11:455-461.

-7 Luo G, Ducy P, McKee MD, Pinero GJ, Loyer E, Behringer RR, Karsenty G: Spontaneous calcification of arteries and cartilage in mice lacking matrix GLA protein. Nature 1997;386:78-81. 


\section{Kidney \\ Blood Pressure Research}

Kidney Blood Press Res 2013;37:15-23

\begin{tabular}{l|l}
\hline DOI: $10.1159 / 000343396$ & C 2013 S. Karger AG, Basel
\end{tabular}

Published onlıne: February 26, 2013

www.karger.com/kbr

Lu/Gao/Yasui/Li/Liu/Mao/Hirose/Wu/Yu/Zhu/Kohri/Xiao: Matrix Gla Protein and Kidney Stone Formation

8 Murshed M, Schinke T, McKee MD, Karsenty G: Extracellular matrix mineralization is regulated locally; different roles of two gla-containing proteins. J Cell Biol 2004;165:625-630.

-9 Gao B, Yasui T, Lu X, Zhou H, Liu J, Liu P, Okada A, Xiao C, Kohri K: Matrix Gla protein expression in NRK-52E cells exposed to oxalate and calcium oxalate monohydrate crystals. Urol Int 2010;85:237-241.

10 Gao B, Yasui T, Itoh Y, Tozawa K, Hayashi Y, Kohri K: A polymorphism of matrix Gla protein gene is associated with kidney stones. J Urol 2007;177:2361-2365.

11 Evan AP, Lingeman JE, Coe FL, Parks JH, Bledsoe SB, Shao Y, Sommer AJ, Paterson RF, Kuo RL, Grynpas M: Randall's plaque of patients with nephrolithiasis begins in basement membranes of thin loops of Henle. J Clin Invest 2003;111:607-616.

12 Yasui T, Fujita K, Sasaki S, Sato M, Sugimoto M, Hirota S, Kitamura Y, Nomura S, Kohri K: Expression of bone matrix proteins in urolithiasis model rats. Urol Res 1999;27:255-261.

-13 Gallagher JC, Riggs BL, Eisman J, Hamstra A, Arnaud SB, DeLuca HF: Intestinal calcium absorption and serum vitamin D metabolites in normal subjects and osteoporotic patients: effect of age and dietary calcium. J Clin Invest 1979;64:729-736.

14 Kumar S, Muchmore A: Tamm-Horsfall protein--uromodulin (1950-1990). Kidney Int 1990;37:1395-1401.

15 Schepers MS, van Ballegooijen ES, Bangma CH, Verkoelen CF: Oxalate is toxic to renal tubular cells only at supraphysiologic concentrations. Kidney Int 2005;68:1660-1669.

16 Schurgers LJ, Cranenburg EC, Vermeer C: Matrix Gla-protein: the calcification inhibitor in need of vitamin K. Thromb Haemost 2008;100:593-603.

17 Wajih N, Borras T, Xue W, Hutson SM, Wallin R: Processing and transport of matrix gamma-carboxyglutamic acid protein and bone morphogenetic protein-2 in cultured human vascular smooth muscle cells: evidence for an uptake mechanism for serum fetuin. J Biol Chem 2004;279:43052-43060.

-18 Chen J, Liu J, Zhang Y, Ye Z, Wang S: Decreased renal vitamin K-dependent gamma-glutamyl carboxylase activity in calcium oxalate calculi patients. Chin Med J (Engl) 2003;116:569-572.

19 Cancela ML, Hu B, Price PA: Effect of cell density and growth factors on matrix GLA protein expression by normal rat kidney cells. J Cell Physiol 1997;171:125-134.

20 Reynolds JL, Joannides AJ, Skepper JN, McNair R, Schurgers LJ, Proudfoot D, Jahnen-Dechent W, Weissberg PL, Shanahan CM: Human vascular smooth muscle cells undergo vesicle-mediated calcification in response to changes in extracellular calcium and phosphate concentrations: a potential mechanism for accelerated vascular calcification in ESRD. J Am Soc Nephrol 2004;15:2857-2867.

-21 Baudet C, Perret E, Delpech B, Kaghad M, Brachet P, Wion D, Caput D: Differentially expressed genes in C6.9 glioma cells during vitamin D-induced cell death program. Cell Death Differ 1998;5:116-125.

-22 Schoppet M, Al-Fakhri N, Franke FE, Katz N, Barth PJ, Maisch B, Preissner KT, Hofbauer LC: Localization of osteoprotegerin, tumor necrosis factor-related apoptosis-inducing ligand, and receptor activator of nuclear factor-kappaB ligand in Monckeberg's sclerosis and atherosclerosis. J Clin Endocrinol Metab 2004;89:4104-4112.

23 Price PA, Faus SA, Williamson MK: Warfarin causes rapid calcification of the elastic lamellae in rat arteries and heart valves. Arterioscler Thromb Vasc Biol 1998;18:1400-1407.

24 Lian JB, Prien EL, Jr, Glimcher MJ, Gallop PM: The presence of protein-bound gamma-carboxyglutamic acid in calcium-containing renal calculi. J Clin Invest 1977;59:1151-1157. 